\title{
PERAN PERPUSTAKAAN SD ISLAM AL-AZHAR 21 PONTIANAK DALAM MENDUKUNG PROSES PEMBELAJARAN ONLINE SELAMA PANDEMI COVID-19
}

\author{
Putri Salsa Anuri1), Atiqa Nur Latifa Hanum²) \\ 1, 2) Fakultas Keguruan dan Ilmu Pendidikan, Universitas Tanjungpura, Pontianak, Indonesia \\ 1) putrisalsa@student.untan.ac.id
}

\begin{abstract}
ABSTRAK
Fokus penelitian membahas peranan pusat sumber belajar Raudhatul Ilmi dalam mendukung proses pembelajaran online pada masa pandemic Covid-19 di SD Islam Al-Azhar 21 Pontianak. Tujuan penelitian untuk mendiskripsikan peran PSB Raudhatul Ilmi dalam mendukung proses pembelajaran online pada masa pandemic Covid19, upaya yang dilakukan pustakawan dalam mengelola PSB Raudhatul Ilmi agar tidak kehilangan perannya pada masa pandemic Covid-19, dan kendala yang dihadapi PSB Raudhatul Ilmi dalam mendukung proses pembelajaran online pada masa pandemic Covid19 di SD Islam Al-Azhar 21 Pontianak. Penelitian ini menggunakan metode deskriptif dengan pendekatan kualitatif, jumlah informan ada dua orang yaitu wakil kepala sekolah dan pustakawan. Sedangkan teknik pengumpulan data yaitu observasi partisipatif, wawancara, dan dokumentasi. Teknik analisis data melalui tahap reduksi data, penyajian data dan pengambilan kesimpulan atau verifikasi. Hasil penelitian menunjukkan bahwa kurang berperannya PSB Raudhatul Ilmi dalam mendukung proses pembelajaran online pada masa pandemic Covid-19. PSB Raudhatul Ilmi hanya berperan untuk guru daripada peserta didik. PSB Raudhatul Ilmi tidak memiliki upaya yang dapat dilakukan pustakawan agar PSB tetap dapat menjalankan perannya, serta terdapat beberapa kendala yaitu kendala waktu yang terbatas untuk pembelajaran online, koleksi yang mendukung dalam pembelajaran online masih berbentuk cetak, tidak adanya pengunjungan dan peminjaman koleksi pada masa pandemic Covid-19.
\end{abstract}

\section{ABSTRACT}

The research focus discusses the role of the Raudhatul Ilmi learning resource center in supporting the online learning process during the Covid-19 pandemic at Al-Azhar Islamic Elementary School 21 Pontianak. The purpose of the study is to describe the role of PSB Raudhatul Ilmi in supporting the online learning process during the Covid-19 pandemic, efforts made by librarians in managing PSB Raudhatul Ilmi so as not to lose their role during the Covid-19 pandemic, and the obstacles faced by PSB Raudhatul Ilmi in supporting the online learning process during the Covid-19 pandemic at Al-Azhar Islamic Elementary School 21 Pontianak. This research uses descriptive methods with qualitative approaches, the number of informants there are two people, namely the deputy principal and the librarian. While data collection techniques are participatory observation, interviews, and documentation. Data analysis techniques through the stages of

\section{ARTIKEL INFO}

Diterima: 23 November 2021

Direvisi: 03 Desember 2021

Disetujui: 24 Desember 2021

\section{KATA KUNCI}

Perpustakaan Sekolah Pembelajaran Online Pandemi Covid-19

\section{KEYWORDS}

School Libraries Online Learning Covid-19 Pandemic 
data reduction, data presentation and conclusion or verification. The results showed that the lack of role of PSB Raudhatul Ilmi in supporting the online learning process during Covid-19 pandemic. PSB Raudhatul Ilmi only plays a role for teachers rather than learners. PSB Raudhatul Ilmi does not have the efforts that librarians can make so that PSB can still carry out its role, and there are some obstacles, namely limited time constraints for online learning, collections that support online learning are still in print, the absence of collection visitors and loans during the Covid-19 pandemic.

\section{Pendahuluan}

Pandemi Covid-19 telah memasuki wilayah Indonesia sejak 2 Maret 2020 lalu dan membawa pengaruh besar terhadap kehidupan masyarakat, baik itu di Indonesia ataupun negara lain yang juga terinfeksi wabah virus tersebut. Pengaruh tersebut dirasakan oleh berbagai aspek kehidupan, salah satunya pada pendidikan di Indonesia berupa kegiatan belajar mengajar. Hal tersebut terlihat dari adanya Surat Edaran Kementerian Pendidikan dan Kebudayaan (Kemendikbud) No.1 Tahun 2020 (dalam Handarini dan Wulandari, 2020, hlm. 496) mengenai pencegahan penyebaran Covid-19 di dunia pendidikan. Dalam surat edaran tersebut Kemendikbud menginstruksikan untuk menyelenggarakan pembelajaran jarak jauh dan menyarankan para peserta didik untuk belajar dari rumah masing-masing. Kegiatan belajar mengajar yang biasanya dilakukan dengan cara tatap muka langsung di kelas, diganti dengan sistem pembelajaran daring.

Perpustakaan merupakan media dan sarana yang dibutuhkan dalam menunjang pendidikan, dari tingkat Sekolah Dasar sampai Perguruan Tinggi perpustakaan menjadi tempat yang menyediakan sumber informasi yang relevan dengan kebutuhan pemakainya. Keberadaan perpustakaan sekolah memiliki tujuan untuk menghimpun koleksi bahan pustaka guna membantu proses pembelajaran yang dilakukan oleh guru dan siswa sekolah tersebut (Bafadal, 2014, hlm. 5). Peran perpustakaan sekolah dalam mendukung proses pembelajaran itu sangat penting karena perpustakaan sekolah sebagai bagian yang tidak terpisahkan dari program penyelenggaraan pendidikan sekolah yang diharapkan dapat mendukung pencapaian tujuan pendidikan. Hartono (2016, hlm. 30-31) menyatakan, "Fungsi perpustakaan sekolah yaitu fungsi pendidikan, fungsi penyimpanan, fungsi penelitian, fungsi informasi, serta fungsi rekreasi dan kultural." Terutama dengan adanya kegiatan belajar mengajar secara daring seperti saat ini, perpustakaan sekolah harus tetap menjadi garda terdepan dalam memberikan sumber informasi yang relevan dan bermanfaat kepada para guru atau peserta didik.
Perpustakaan sekolah berada di bawah naungan sekolah. Penyelenggaraan perpustakaan sekolah itu sendiri mengacu kepada UndangUndang Nomor 2 Tahun 1989 tentang Sistem Pendidikan Nasional. Di mana pada Pasal 35 Undang-Undang tersebut dikemukakan bahwa setiap satuan pendidikan jalur pendidikan sekolah, baik yang diselenggarakan oleh pemerintah maupun oleh masyarakat, harus menyediakan sumber-sumber belajar. Dalam penjelasan Pasal 35 tersebut dikemukakan bahwa salah satu sumber belajar yang amat penting tetapi bukan satusatunya adalah perpustakaan, yang harus memungkinkan para tenaga kependidikan dan para peserta didik memperoleh kesempatan untuk memperluas dan memperdalam pengetahuan melalui membaca buku dan koleksi lain yang diperlukan (dalam Yusuf dan Suhendar, 2016, hlm. 2).

Pandemi Covid-19 membawa tantangan baru bagi pustakawan sekolah. Keberadaan perpustakaan tidak boleh hilang dalam menjalankan perannya sebagai pusat penyedia berbagai informasi. Dengan demikian, perpustakaan sekolah harus berinovasi agar dapat memudahkan akses layanan sehingga dapat membantu kegiatan belajar mengajar yang dilakukan secara daring. Modernisasi perpustakaan telah diadopsi dalam Undang-Undang Nomor 43 Tahun 2007 Bab V pasal 14 ayat 3 tentang perpustakaan disebutkan bahwa setiap perpustakaan mengembangkan layanan perpustakaan sesuai dengan kemajuan teknologi informasi dan komunikasi (dalam Hartono, 2017, hlm. 5). Dengan adanya bantuan teknologi dan informasi maka pekerjaan yang dilakukan pustakawan dapat diselesaikan dengan cepat dan mudah, serta masyarakat dapat mengakses informasi secara online.

Berdasarkan penjelasan tersebut, dari pengamatan yang dilakukan oleh peneliti di SD Islam Al-Azhar 21 Pontianak peneliti menemukan beberapa masalah yang ada di PSB Raudhatul Ilmi yaitu koleksi yang ada hanya berbentuk tercetak sehingga tidak dapat diakses secara online oleh para peserta didik di masa pandemi Covid-19, kurangnya inisiatif pustakawan untuk menyebarluaskan 
koleksi sehingga menjadi faktor penyebab kurangnya pemanfaatan koleksi. Beberapa masalah tersebut membuat Pusat Sumber Belajar Raudhatul Ilmi di SD Islam Al-Azhar 21 Pontianak saat ini kehilangan perannya dalam mendukung proses pembelajaran online. Berdasarkan pembahasan tersebut peneliti sangat tertarik untuk mengangkat judul tentang Peran Pusat Sumber Belajar Raudhatul Ilmi Dalam Mendukung Proses Pembelajaran Online Pada Masa Pandemi Covid-19 di SD Islam Al-Azhar 21 Pontianak.

\section{Metode Penelitian}

Penulis menggunakan metode deskriptif dengan pendekatan kualitatif. Pengumpulan data dilakukan dengan observasi langsung di lapangan disertai dengan wawancara secara online melalui Google Meet bersama wakil kepala sekolah yang juga menjabat sebagai guru dan pustakawan, serta dokumentasi yang berkaitan dengan penelitian. Sumber data yang diperoleh adalah sumber primer dan sumber sekunder. Alat pengumpul data yaitu pedoman wawancara yang berisi pertanyaanpertanyaan berdasarkan kebutuhan informasi yang dibutuhkan dari informan, alat tulis, dan telepon seluler untuk merekam hasil wawancara. Data yang diperoleh kemudian diolah oleh penulis berdasarkan tahap analisis data berupa reduksi data, penyajian data, dan pengambilan kesimpulan atau verifikasi.

\section{Hasil dan Pembahasan Hasil}

Penelitian ini berfokus pada peran perpustakaan sekolah dalam mendukung proses pembelajaran online. Permasalahan yang dibahas yaitu tentang "Peran perpustakaan SD Islam AlAzhar 21 Pontianak dalam Mendukung Proses Pembelajaran Online selama Pandemi Covid-19". Adapun data dan informasi yang diperoleh untuk mengetahui lebih lanjut mengenai peran PSB Raudhatul Ilmi didapatkan melalui pengamatan langsung dari bulan Maret 2021 hingga bulan Juli 2021. Hasil penelitian juga diperoleh dari kegiatan wawancara yang dilakukan bersama dua informan dengan memberikan pertanyaan-pertanyaan yang telah disiapkan di pedoman wawancara.

\section{Pembahasan \\ Peran PSB Raudhatul Ilmi dalam Mendukung Proses Pembelajaran Online Pada Masa Pandemi Covid-19 di SD Islam Al-Azhar 21 Pontianak}

Wabah virus Covid-19 merupakan wabah virus yang harus di waspadai karena dapat menulari antar manusia yang saling berinteraksi bahkan dapat menyebabkan kematian. Pandemi akibat virus tersebut mengharuskan kegiatan pembelajaran di semua jenjang pendidikan dilakukan secara daring menggunakan teknologi dan berbagai aplikasi dengan jaringan internet yang dapat digunakan untuk mendukung kelancaran proses pembelajaran daring. Penggunaan internet dan teknologi sebagai media untuk menjalankan aplikasi pembelajaran jarak jauh dianggap dapat menjadi alternatif dan mengubah teknik dalam penyampaian ilmu pengetahuan bagi peserta didik (Amalia dan Sa'adah, 2020, hlm. 218).

Pembelajaran daring menjadi hal yang baru bagi dunia pendidikan di Indonesia. Hal tersebut membuat pembelajaran daring ini mendapat berbagai tanggapan dari masyarakat. Berbagai tanggapan tersebut menyebabkan pro dan kontra di lingkungan sekolah dari mulai Sekolah Dasar sampai dengan perguruan tinggi terkait persoalan kesiapan berbagai fasilitas pendukung bagi peserta didik selama belajar online, termasuk perpustakaan yang digunakan sebagai sumber belajar peserta didik kegiatan belajar mengajar (Kusuma, 2020, hlm. 53-54). Keberadaan perpustakaan sangat diperlukan untuk memenuhi kebutuhan informasi, meningkatkan prestasi dan minat baca peserta didik.

Perpustakaan sekolah dasar termasuk ke dalam salah satu jenis perpustakaan sekolah dengan sasaran pengguna merupakan guru-guru dan siswa berusia antara 7-12 tahun. Menurut Suhendar (2014, hlm. 3) Perpustakaan sekolah dasar merupakan perpustakaan yang menyimpan bahan pustaka terkait materi sekolah dasar, baik bahan pustaka cetak maupun noncetak dengan maksud untuk mendukung pembelajaran di sekolah dasar tersebut. Koleksi yang ada disesuaikan dengan kebutuhan para siswa di lingkungan sekolah dasar tersebut. Selain itu, koleksi yang disimpan juga harus sesuai dengan kurikulum sekolah.

Pembelajaran yang dilakukan secara online tentunya tidak selalu berjalan lancar. Kegiatan belajar mengajar yang dilakukan secara online membutuhkan akses internet yang lancar untuk memudahkan peserta didik memperoleh sumbersumber belajar yang mendukung pembelajaran online tersebut. Dengan adanya permasalahan akses internet yang tidak lancar maka menyebabkan peserta didik kesulitan untuk mengakses sumber belajar secara daring. Hal itu membuat perpustakaan dianggap sebagai sarana utama dalam membantu dan memudahkan peserta didik memperoleh sumber belajar yang dibutuhkan. Perubahan dan perkembangan zaman tidak membuat perpustakaan kehilangan fungsi sebagai penyedia kebutuhan informasi yang paling utama (Ramadhanti dkk, 2020, hlm. 4-5). 
Perpustakaan merupakan salah satu sarana pendukung yang menyediakan berbagai macam sumber informasi dari koleksi-koleksi yang ada agar dapat menjadi referensi bagi para penggunanya dalam membantu aktivitas belajar yang dilakukan. Peran perpustakaan sangat diperlukan dalam mendukung kelancaran proses pembelajaran di sekolah. Kedudukan perpustakaan dianggap mampu menjadi penyalur bagi perubahan, pembangunan, budaya serta pengembangan ilmu pengetahuan dan teknologi (Suwarno, 2014, hlm. 45). Pada kondisi pandemi Covid-19 saat ini, perpustakaan harus tetap menjalankan perannya dalam mendukung proses pembelajaran yang dilakukan secara online. Menurut Darmanto (2020, hlm. 4) Perpustakaan berperan sebagai tempat untuk mendapatkan pendidikan nonformal yang mempunyai tugas untuk mengumpulkan, mengolah, serta mendayagunakan koleksi untuk kebutuhan pemustaka.

Selama pandemi Covid-19 SD Islam Al-Azhar 21 Pontianak melakukan proses pembelajaran online lewat zoom meeting sehingga membuat PSB Raudhatul Ilmi tidak dapat menjalankan seluruh program yang ada. Tidak semua guru memasukkan program PSB ke dalam pembelajaran online. Beberapa guru lebih fokus untuk mengejar materi yang ada. Namun, ada juga yang memasukkan program PSB dengan memberikan waktu untuk peserta didik menonton dari VCD yang dipinjam di PSB dan tontonan tersebut berdasarkan materi yang sedang dipelajari, serta tetap membudayakan membaca buku sebelum pembelajaran dimulai diganti dengan buku yang dimiliki di rumah masingmasing agar tetap meningkatkan minat baca peserta didik meski pembelajaran online.

PSB Raudhatul Ilmi masih kurang berperan selama pandemi Covid-19 dalam mendukung proses pembelajaran online karena hanya berperan pada guru yang mengajar di sekolah daripada peserta didik, kemudian pustakawan yang mengelola PSB tidak dapat memberikan pelayanan koleksi di perpustakaan sehingga koleksi-koleksi yang ada tidak dapat dipinjam dan dimanfaatkan oleh para peserta didik selama pembelajaran online. PSB Raudhatul Ilmi hanya berperan dalam menyediakan dan memberikan sumber informasi yang dibutuhkan oleh guru untuk membantu mereka dalam menyiapkan sarana pembelajaran bagi para peserta didik.

PSB Raudhatul Ilmi sudah memiliki koleksi yang lengkap dan sesuai dengan kurikulum sekolah sehingga dapat mendukung proses pembelajaran secara online, namun koleksi tersebut hanya berbentuk koleksi cetak. PSB Raudhatul Ilmi tidak memiliki koleksi non cetak yang bisa didapat peserta didik melalui perangkat elektronik mereka, sehingga PSB Raudhatul Ilmi tidak dapat dimanfaatkan secara maksimal selama pandemi Covid-19. Menurut Prastowo (2018, hlm. 106) Kemajuan teknologi informasi dan komunikasi membuat perpustakaan harus mengembangkan koleksi perpustakaan. Faktor yang menjadi penyebab PSB Raudhatul Ilmi tidak memiliki koleksi non cetak karena pertimbangan mengenai perkembangan anak usia dasar yang tidak baik jika terlalu lama menggunakan gadget dan masih perlu dampingan orang tua untuk memanfaatkan aplikasi online, serta ketidaksiapan program sekolah yang belum ada mengarah ke pemanfaatan aplikasi online.

Menurut Ramadhanti dkk (2020, hlm. 23) demi meningkatkan pembelajaran jarak jauh di masa pandemi Covid-19, perpustakaan memiliki tugas untuki menjadi sarana penyedia sumberi informasi belajar berupa bahan pembelajaran cetak maupun non cetak. Peran PSB Raudhatul Ilmi dari segi koleksi masih belum dapat mendukung proses pembelajaran online selama pandemi Covid-19 secara maksimal, hal itu dikarenakan koleksi yang ada masih berbentuk koleksi cetak dan belum memiliki koleksi non cetak sehingga koleksi tersebut hanya dapat dimanfaatkan oleh guru yang mengajar di sekolah. Perpustakaan sudah dimanfaatkan oleh para guru dan peserta didik selama pembelajaran online walaupun peserta didik tidak bisa memanfaatkan langsung koleksi yang ada, namun peserta didik dapat memanfaatkan koleksi tersebut melalui para guru yang mengajar.

\section{Upaya Pustakawan dalam Mengelola PSB Raudhatul Ilmi agar Tidak Kehilangan Perannya di Masa Pandemi Covid-19}

Pustakawan merupakan seseorang yang memiliki tugas untuk memenuhi pekerjaan terkait dengan perpustakaan baik pengolahan maupun pelayanan. Pustakawan dituntut untuk memiliki banyak pengetahuan dan keterampilan agar lebih aktif dan kreatif dalam menghadapi tantangan di era globalisasi. Menurut Hidayat (2016, hlm. 476) ada empat peran pustakawan di era globalisasi, yaitu pustakawan harus mampu menyediakan sumbersumber koleksi dalam berbagai format dan sarana temu kembali informasi, pustakawan harus mampu memberikan nilai dan informasi yang lebih luas serta mendalam pada koleksi yang ada sehingga pustakawan tidak hanya berperan untuk menjaga koleksi perpustakaan, pustakawan harus dapat menyediakan layanan untuk pemustaka dalam bentuk online selama 24 jam, serta pustakawan harus dapat memberikan jenis layanan yang beragam kepada pengguna perpustakaan.

Pustakawan memiliki peran penting dalam membantu pemustaka untuk mendapatkan sumber 
informasi sesuai dengan kebutuhannya selama pandemi Covid-19. Pustakawan harus dapat mengelola perpustakaan yang merupakan pusat sumber informasi bagi pemustaka agar tetap bisa menyediakan berbagai sumber informasi selama pandemi Covid-19. Pelayanan perpustakaan harus dilakukan secara online dengan menyediakan bahan pustaka yang dibutuhkan pemustaka dan sarana temu balik informasi yang melancarkan pemustaka untuk menemukan bahan pustaka sesuai informasi yang dibutuhkan. Baik atau buruk sebuah perpustakaan dilihat dari kualitas pelayanan yang disediakan oleh perpustakaan tersebut. Oleh karena itu, selama pandemi Covid-19 ini dalam mengelola perpustakaan maka pustakawan harus lebih melihat kualitas layanan yang harus diberikan kepada pemustaka. Pustakawan yang memberikan layanan prima dalam melayani pemustaka sehingga membuat kesan baik dan senang di dalam diri pemustaka tersebut akan membawa figur baik bagi perpustakaan, begitupun sebaliknya (Suharti, 2020, hlm. 55-56).

Pandemi membawa pustakawan agar lebih maju dalam memikirkan berbagai strategi yang dapat melancarkan pelayanan perpustakaan. Pustakawan yang kreatif sangat diperlukan dalam mengelola perpustakaan, terutama dalam kondisi pandemi saat ini. Dengan berbagai ide yang dimiliki pustakawan maka dapat membantu dalam pengelolaan perpustakaan agar dapat berguna untuk mengatasi kebingungan para pemustaka dalam mendapatkan kebutuhan informasi. Pustakawan harus lebih berpikir cara menyesuaikan kondisi yang ada dengan keberadaan teknologi informasi. Pemanfaatan teknologi informasi dengan kemajuan berpikir dan kreatifitas pustakawan dapat membantu mewujudkan tujuan diselenggarakannya perpustakaan meski dalam kondisi pandemi.

Perkembangan teknologi informasi dan komunikasi membawa tantangan bagi pustakawan dalam mengelola perpustakaan. Pustakawan harus lebih aktif dalam memberikan jasanya untuk melayani pengguna. Selain itu, penting bagi pustakawan meningkatkan kualitas layanan dengan memakai sosial media dalam menyebarluaskan berbagai hal kepada pengguna (Ramadhanti, 2020, hlm. 22). Selama pembelajaran online, pengelolaan PSB Raudhatul Ilmi dilakukan seperti biasanya, koleksi yang ada baik itu koleksi buku-buku baru pun tidak diinformasikan kepada peserta didik karena peserta didik tidak dapat meminjam buku ke sekolah. Pustakawan PSB Raudhatul Ilmi hanya mengelola dan merapikan koleksi yang ada selama pandemi Covid-19 ini.
Rodin (2017, hlm. 165) menyatakan bahwa pustakawan tidak hanya bertugas untuk mengelola perpustakaan, namun pustakawan dituntut untuk dapat membuat suatu program yang dapat menarik minat pemustaka. Selama pandemi Covid-19 tidak ada upaya apapun yang dilakukan pustakawan agar PSB Raudhatul Ilmi tidak kehilangan perannya dalam mendukung proses pembelajaran online, namun apabila tahun ajaran baru pandemi Covid-19 masih belum selesai maka upaya kedepannya akan ada program yang dibuat oleh pustakawan untuk peserta didik agar dapat memanfaatkan koleksi yang ada di PSB Raudhatul Ilmi.

Kendala yang Dihadapi PSB Raudhatul Ilmi dalam Mendukung Proses Pembelajaran Online pada Masa Pandemi Covid-19

Sebagai pusat sumber informasi, rintangan atau kelemahan tentu dimiliki oleh perpustakaan dalam menjalankan tugas untuk melayani pengguna. Kendala yang dihadapi perpustakaan merupakan hal yang pasti terjadi dan perlu dilalui setiap perpustakaan. Kendala ini membuat perpustakaan harus melakukan segala hal untuk dapat menyelesaikan permasalahan yang ada agar perpustakaan tetap dapat melaksanakan tujuannya dan menjalankan perannya di dunia pendidikan. Kendala tersebut tentu dapat diatasi tergantung pada pengelola perpustakaan dalam memperbaiki permasalahan yang ada agar menjadi lebih baik.

Permasalahan yang dialami sebuah perpustakaan tidak boleh membuat perpustakaan tersebut melupakan tugasnya. Masalah yang ada harus segerasa diatasi dan diselesaikan dengan kerjasama berbagai pihak yang bersangkutan dalam penyelenggaraan perpustakaan. Kerjasama yang baik tentunya akan dapat menyelesaikan permasalahan dan dapat meningkatkan hubungan yang baik antar pengelola perpustakaan. Kendala yang teratasi juga dapat meningkatkan kualitas kerja pengelola perpustakaan dalam menjalankan tugasnya.

Selama pembelajaran online, PSB Raudhatul Ilmi tidak dapat menghimpun koleksi yang ada kepada para peserta didik dikarenakan koleksi di PSB hanya berbentuk koleksi cetak. Hal tersebut tentunya menjadi salah satu kendala PSB Raudhatul Ilmi dalam mendukung proses pembelajaran online. Selain itu, yang menjadi kendala PSB Raudhatul Ilmi adalah waktu dalam pertemuan zoom meeting yang sedikit dan materi pembelajaran yang sudah full menyesuaikan waktu tersebut sehingga program yang selama ini dijalankan saat pertemuan tatap muka di sekolah tidak terjalankan sepenuhnya dalam pembelajaran online, serta tidak ada pengunjungan dan peminjaman membuat pustakawan kesulitan untuk membuat laporan 
untuk diserahkan ke diknas maupun kepsek dan grafik pengunjungan serta peminjaman.

\section{Simpulan}

Berdasarkan hasil penelitian tentang peran PSB Raudhatul Ilmi SD Islam Al-Azhar 21 Pontianak maka dapat ditarik kesimpulan yaitu: Peran PSB Raudhatul Ilmi dalam mendukung proses pembelajaran online selama pandemi Covid-19 lebih berperan untuk para guru yang mengajar di sekolah dari pada peserta didik, terlihat tidak sepenuhnya program PSB dapat dijalankan dalam proses pembelajaran online, kemudian koleksi PSB sudah mendukung proses belajar mengajar dan sesuai dengan kurikulum namun tidak dapat dimanfaatkan secara langsung oleh peserta didik karena masih berbentuk koleksi cetak sehingga selama pembelajaran online PSB hanya menyediakan buku-buku penunjang bagi guru yang mengajar, serta selama pandemi Covid-19 pustakawan tidak melayani peminjaman koleksi dan peserta didik juga tidak dapat datang ke sekolah untuk meminjam koleksi PSB.

Dalam mengelola PSB Raudhatul Ilmi selama pandemi Covid-19, pustakawan tidak ada melakukan upaya apapun agar PSB Raudhatul Ilmi tetap dapat menjalankan perannya dalam mendukung proses pembelajaran online.

Kendala PSB Raudhatul Ilmi dalam mendukung proses pembelajaran online selama pandemi Covid19 yaitu hanya memiliki koleksi berbentuk cetak, Waktu pembelajaran online sangat sedikit sehingga tidak semua guru dapat menjalankan program PSB dikarenakan guru-guru hanya fokus mengejar pembelajaran dengan materi yang full, serta tidak ada peminjaman koleksi dan pengunjungan ke PSB sehingga pustakawan kesulitan untuk membuat grafik maupun laporan untuk diserahkan ke diknas dan kepsek.

\section{Daftar Pustaka}

Amalia, A., \& Sa'adah, N. (2020). Dampak Wabah Covid-19 Terhadap Kegiatan Belajar Mengajar Di Indonesia. Jurnal Psikologi, 13(2),

214-225. https://doi.org/10.35760/psi.2020.v13i2. 3572

Bafadal, I. (2014). Pengelolaan Perpustakaan Sekolah. Jakarta: Bumi Aksara

Darmanto, P. (2020). Manajemen Perpustakaan. Jakarta: Bumi Aksara.

Handarini, O. I., \& Wulandari, S.S. (2020). Pembelajaran Daring Sebagai Upaya Study From Home (SFH) Selama Pandemi Covid
19. Jurnal Pendidikan Administrasi Perkantoran (JPAP) 8 (3), 496-503. https://journal.unesa.ac.id/index.php/jpa $\mathrm{p}$

Hartono. (2016). Manajemen Perpustakaan Sekolah/Madrasah: menuju perpustakaan modern dan profesional. Ar-Ruzz Media.

Hartono. (2017). Manajemen Sistem Informasi Perpustakaan: konsep, teori dan implementasi. Yogyakarta: Gava Media.

Hidayat, A. (2017). Rekonstruksi Peran Pustakawan Di Era Globalisasi. LIBRARIA: Jurnal Perpustakaan, 4(2), 467. https://doi.org/10.21043/libraria.v4i2.18 72

Kusuma, A. (2020). Dukungan Perpustakaan dalam Proses Pembelajaran Online di Universitas Islam Negeri Sunan Kalijaga pada Masa Pandemic Covid-19. Libria, 12(1), 51-70. https://jurnal.arraniry.ac.id/index.php/libria/article/view 17685

Prastowo, A. (2018). Sumber Belajar \& Pusat Sumber Belajar: teori dan aplikasinya di Sekolah/Madrasah. Depok: Prenadamedia Group.

Ramadhanti, D. (2021). Peran Perpustakaan Sebagai Pendukung Pembelajaran Jarak Jauh di Masa Pandemi Covid-19. Libraria, Vol. 8(No. 1), 1-30.

Rodin, R. (2017). Pustakawan Profesional di Era Digital: meningkatkan kreativitas inovatif dan profesionalitas pustakawan. Yogyakarta: Suluh Media.

Suharti AD. (2020). Layanan Perpustakaan Di Masa Pandemi. Buletin Perpustakaan Universitas Islam Indonesia, 3(2), 53-63.

Suhendar, Y., \& Yusuf, P. M. (2016). Pedoman Penyelenggaraan Perpustakaan Sekolah. Jakarta: Prenada Media Group.

Suhendar, Y. (2014). Panduan Petugas Perpustakaan: cara mengelola perpustakaan Sekolah Dasar. Jakarta: Prenadamedia Group.

Suwarno, W. (2014). Dasar-Dasar Ilmu Perpustakaan: sebuah pendekatan praktis. Yogyakarta: Ar-Ruzz Media. 